\title{
DIFFERENTIATED INTEGRATION IN A CANDIDATE STATE: THE CASE OF TURKISH TRANSPORT*
}

\section{Ahmet Cemal ERTÜRK**}

\section{Abstract}

EU-Turkey relations are currently in an impasse where each side tries to survive the integration process in different ways. Although the optimism of the last decade has clearly gone, there are still hopes for new measures to speed up the alignment of Turkey to the EU. In particular, differentiated integration offers new flexible arrangements for non-member and candidate states to opt-in to selected EU acquis without engaging in wider uniformity and threatening their national sovereignty. EU-Turkey relations on transport are a relatively successful alignment case during these turbulent times. The settled pattern of selective participation in transport policy results from the alternative approach taken by the parties based on transport programs, funding mechanisms and created institutional bodies. This study analyzes this selective participation pattern in the case of transport as an example of differentiated integration and explores the reasons behind Turkey's decision to opt-in. As selective participation leads to selective implementation, the alignment decisions of Turkish officials strongly depend on domestic political preferences and the number of supporting non-state actors. This study therefore also investigates the domestic and external factors that led Turkey to selective participation and implementation. The results of the case provide an effective example for other policy areas that need motivation on alignment.

Keywords: Transport, differentiated integration, European Union, Turkey.

* This article builds on the author's Ph.D. dissertation entitled "Turkey's Alignment to the European Union's Transport Policy: Revisiting the Integration Theories".

** Dr., Istanbul Kultur University, Faculty of Economics and Administrative Sciences, Department of International Relations, e-mail: a.erturk@iku.edu.tr 


\section{AB'YE ADAY ÜLKELERDE \\ FARKLILAŞTIRILMIŞ ENTEGRASYON HAREKETLERI: TÜRKIYE ULAŞTIRMA POLITIKKALARI ÖRNEĞI}

\section{$\ddot{O} z$}

Son ylllarda değişkenlik gösteren dlş politika ĕgilimleri ile birlikte, ABTürkiye ilişkileri bir çıkmaza girmiştir. Özellikle iki tarafin entegrasyon algısının bir hayli farklılaştığı şu günlerde, tam üyelik için iyimser anlayış ortadan kalkmıştır. Fakat hala Türkiye'nin AB'ye uyum sürecini hızlandıracak tedbirler ve hamleler mevcuttur. Farklılaştırlmış entegrasyon, üye olmayan ve aday ülkelere ulusal çıkarlarını ve duruşlarını fazlasıyla tehdit etmeden, seçili $A B$ müktesebatı üzerinden yeni esnek düzenlemeler sunmaktadır. Türkiye ve $A B$ arasındaki ulaştırma politikaları uyum süreci buna önemli bir örnek teşkil etmektedir. Türkiye'nin AB Ulaştırma Politikalarına katılımı ülkenin üyelik süreci sekteye uğramasına rağmen $A B$ ulaşım programlarına, finansman mekanizmalarına, kurumsal organlarına alternatif yollar kullanarak girmesiyle tanımlanabilmektedir. Bu çalışma, farklılaştırılmış entegrasyonun bir örneğ $i$ olarak Türkiye ulaştırma sektörünün AB müktesebatına seçici katılım modelini analiz etmekte ve Türkiye'nin bu katılım kararın arkasındaki nedenleri incelemektedir.

Anahtar Kelimeler: Ulaştırma, farklılaştırılmış entegrasyon, Avrupa Birliği, Türkiye.

\section{Introduction}

After nearly sixty years of close cooperation, it is clear that EU-Turkey relations have reached an impasse. The optimistic tone of the previous fourteen years since the start of membership negotiations in 2005 has been transformed into an uncertain future with many disagreements between the parties. Meanwhile, both the EU and Turkey are currently preoccupied with internal challenges. The EU is still searching for answers to the problem of rising nationalism and refugee crisis while Turkey is facing a transition period to a new governance model. Although they are still strongly economically interdependent, the EU and Turkey are now more focused on bilateral agreements to resolve shared issues rather than waiting for Turkey's full conformity with the EU acquis. The refugee agreement is a prominent example of this approach.

These turbulent relations in recent years have clearly affected Turkish alignment to the EU acquis communautaire in general. At last year's State of 
Union Address, European Commission President Jean Claude Juncker criticized Turkey regarding free speech and human rights, and vowed that Turkish membership was not on the horizon (European Commission, 2017a). In response, Turkish President Recep Tayyip Erdogan criticized the EU for allegedly breaking its promises and claimed that Turkey does not need the EU any more (DW, 2017). Given this cloudy picture, Turkey's full alignment seems infeasible at the moment. However, against all the odds, one particular policy area - transport - has seen effective developments regarding EU alignment whereby Turkey has achieved relatively strong compliance with the EU acquis despite current difficulties.

Transport policy and alignment are important for both parties for obvious reasons. The first is the enduring economic interdependence between the EU and Turkey. Transport is an indispensable factor in the "free movement of goods" clause of the Customs Union within which the EU currently takes $51.2 \%$ of Turkish exports (Turkish Statistical Institute, 2018). The second reason is geography. As well as being a significant market for the EU, Turkey is a transport gateway for member states to reach Eastern markets. Third, transport is involved in two significant negotiation chapters (Chapters 14 and 21), with which Turkey should comply to achieve EU membership. Finally, transport also symbolizes a curious success in a fraught period of relations, which makes it worth further research. These factors encourage the investigation of the reasons behind this healthy relationship in a highly conflicted era to answer the following question: "To what extent and how is Turkish transport aligned to the European Union?" The aims of asking this are to understand progress in this policy area and provide an alternative framework for other policy areas to thrive, even in these turbulent years.

In this regard, the argument of this article is that this strong compliance and continuity in transport is linked to the permanency of domestic political interests and endured support of non-state actors, which pushed Turkey to create alternative or flexible new channels outside of the general membership spectrum and depending on new dialogue and alignment instruments. This flexible rapprochement applied to the transport relations could be explained through the concept of differentiated integration. For understanding the reasons behind choosing this selective approach and main motivations of the Turkish decision-makers, rationalist institutionalism will be applied.

Differentiated integration in EU-Turkey relations is not new. Within this nearly sixty-year cooperation, both sides have created alternative instruments and communication channels to move forward on alignment and keep Turkey inside the integration process by opting-in as a candidate state. According to Muftuler Bac and Luetgert (2016: 6-12), Turkey's integration already differed from other countries' in the Customs Union decision of 1995 and Turkey's 
involvement in community programs since 1999, to maximize the EU's integration capacity in Turkey as an alternative to full membership. The latest example of these optional channels is the recent EU-Turkey deal on refugees. This flexible approach has also been implemented in transport policy. In contrast to the EU's usual "one-size-fits-all" model (Muftuler-Bac and Luetgert, 2016: 6), the EU and Turkey have encouraged alignment by developing new financial agreements, bilateral transport deal negotiations, new institutions and EU investment in Turkish transport projects. This selective participation or "opt-in" decision is thus a case of selective implementation. We argue that the selective implementation of the EU transport acquis in Turkey is closely related to domestic drivers, such as alignment of domestic transport preferences with the EU acquis and supportive non-state institutions. The following sections outline the definition of differentiated integration, briefly analyze the differentiation of Turkish integration with the EU and discuss transport policy as an example of Turkey's new flexible approach.

\section{Differentiated Integration}

The emergence of the concept within EU studies dates back to the postMaastricht 1990s. Currently, "differentiated integration" is used to explain the future of the integration process after many crises that the EU has faced in the last decade (Leruth et al., 2017: 3). Differentiated integration explains variations in the level and scope of state participation in the EU acquis (Wallace, 1998: 137). The rising number of both member and candidate states has frequently raised the question of how to deal with different national concerns and competences. Differentiated integration has thus become a useful instrument to enable the EU to maintain integration by ensuring a flexible approach. This approach enables the EU to construct flexible arrangements for a deeper trade-off with willing states and makes it possible for unwilling states to join when they are ready (Zhelyazkova, 2014: 727). Therefore, as an alternative to full accession, differentiated integration offers a model of integration-maximization for countries that are not yet ready for full accession (Muftuler Bac and Luetgert, 2016: 6-7). The European Neighborhood Policy is a significant example for the emergence of this approach (Muftuler Bac and Luetgert, 2016: 6-7). The EU itself characterizes differentiated integration as a flexible arrangement concerning member state participation in various policy areas in an "a la carte Europe" fashion whereby non-member states may also rejoin the EU on selected policy areas, such as the Euro and the Schengen Area (European Parliament, 2016).

Schimmelfenning, Leuffen and Rittberger (2015) claim that differentiation is essential for any integration process and a likely outcome of developing supranational policies. The demand for differentiation originates from deepening responses to member state concerns about protecting domestic 
interests (Schimmelfennig, 2018: 1157). Schimmelfennig (2018: 1157) argues that the demand for differentiated integration is particularly strong in countries with exclusivist national identities that are more prone to selectivity based on national interest (Schimmelfennig, 2018: 1157). Schimmelfennig et al. (2015: 765 ) suggest two different models of differentiated integration. The first model is the vertical differentiation, where policy areas have been integrated but at different speeds and levels between member states (Schimmelfennig et al., 2015: 765). Secondly, horizontal differentiation assumes many integrated policies that are neither uniform nor exclusively for member or non-member states (Schimmelfennig et al., 2015: 765). If a member state chooses to exclude itself from a particular EU policy, then the model is one of internal horizontal differentiation whereas if a non-member state chooses to opt in to a particular EU policy, then it signifies external horizontal differentiation (Schimmelfennig et al., 2015: 765). The explanatory elements for these models to occur are settled interdependence and politicization (Schimmelfennig et al., 2015: 765). Interdependence drives the integration process arising from the basic demand for alignment while politicization creates obstacles for the dynamism of the process (Schimmelfennig et al., 2015: 765).

The literature offers various discussions regarding the applicability of the concept to non-member or candidate states, such as Holzinger and Schimmelfennig (2012), who argue that the idea of external governance, whereby a non-member state selectively approves the EU's acquis for a specific sector, is an enduring part of the history of European integration. They suggest that the differentiated structure of non-member integration is inevitable since different standards of different groups will endure while their loyalty to the acquis will always depend on national preferences. This then raises the question of how non-member states respond when they get the opportunity to selectively opt-in to a specific part of the EU acquis. Regarding the relationship between selective integration and implementation, Asya Zhelyazkova (2014) explains how different levels of participation affect national policy outcomes. She concludes that although differentiated integration is a necessity for both the EU and member states because of constructed interdependence, it also increases the implementation gap between member and non-member states (Zhelyazkova, 2014: 727). She criticizes the general expectation that states choosing to comply will perform as well as fully integrated members when it comes to alignment (Zhelyazkova, 2014: 727). Instead, she assumes that of the three types of states (full participants, selective participants and non-participants), selective participants are more likely to implement better than non-participants although not nearly as much as full participants because selective participation leads to selective implementation based on domestic preferences (Zhelyazkova, 2014: 727). 
Yet another discussion point about the concept is the nature of differentiation. It is clear from the literature that the concept serves as a crisis solution mechanism. The EU itself also evaluates the concept as an alternative to full alignment rather than a naturally occurring phenomenon (European Parliament, 2016). However, scholars like Leruth, Ganzle and Trondal (2017) have challenged this limited view by reviewing opting out as a naturally developed instrument against theories that consider it as a mere solution to sovereignty challenges. They argue that only a few EU policy areas are exclusive whereas most are willingly regulated by member states, so the concept should not be limited to a crisis response mechanism (Leruth et al., 2017). Andersen and Sitter (2006) narrowed down the concept to a member or non-member state's simple choice whether to participate. This depends on their willingness to actively participate in a specific sector of the acquis.

Different conceptual explanations suggest different meanings of domestic national choices regarding differentiated integration. National preferences are assumed to shape a member state's choice of opting-in or opting-out. Two studies have investigated the evolution of the relevant domestic preferences and actors. First, Mutfuler Bac and Luetgert (2016:8) suggest that the domestic preferences and political realities of existing EU member drive integration outcomes. Second, Fumasoli, Gornitzka and Leruth (2015) focus on the domestic decision-making mechanisms that drive a member or non-member state towards selective participation. They conclude that the degree of interdependence and politicization both depend on calculating the costs of integration. This takes place within a multi-level policy framework in which member states, regions, cities, non-governmental organizations and private corporations can measure the costs and benefits of opting-in.

\section{Turkey's path to Differentiated Integration}

In Turkey, there were hopes for uniform integration at the start of new millennium after the country gained official candidate status at the 1999 Helsinki Summit and negotiations began in 2005. However, the prospect of full membership has faded since 2005 as the rather uncompromising behavior of both parties has stalled Turkey's membership bid. This loss of momentum can be understood in terms of changing political dynamics within both the EU and Turkey. In Turkey, the key factor was the clear change to the country's foreign policy stance under the AKP government (Onis, 2008:40). The EU responded by questioning Turkey's credentials for EU candidacy (Onis, 2008: 41). These political disturbances encouraged leaders like Merkel and Sarkozy to suggest "privileged partnership" as an alternative of loose cooperation instead of uniform integration. Although Turkey was still considered as an important ally, EU members started express concerns, such as the possible administrative costs of Turkey's membership and the EU's lack of absorption capacity (İcener, 
2007: 422-23). As recently as 2018, French President Macron claimed that Turkey remains far from becoming a member state and revived the idea of privileged partnership (BBC, 2018). Turkey rejected the proposal and stated that a second-class status was not acceptable (Sputnik News, 2018). Nevertheless, the two sides' high interdependence created political problems that forced them to search for alternative models of alignment.

Regarding alignment with the EU acquis, Turkey's path has differed from other candidate states since the beginning of the accession process. Specifically, the 1995 decision to form a Customs Union started an alternative economic integration route for Turkey (Muftuler Bac and Luetgert, 2016: 12). This new route has created new alignment methods with more flexible arrangements, such as including Turkey in community programs after its candidacy (Muftuler Bac and Luetgert, 2016: 12). With the help of these new arrangements, Turkey and the EU have tried to reinvigorate the alignment process. According to Muftuler Bac (2017: 424), by using alternative methods, Turkey is now aligned in many policy areas and has selectively complied with the EU acquis communitaire. Examples include the instrumentality of the Customs Union and Turkey's inclusion in selected lines of EU foreign and defense, energy and justice and the home affairs policies (Muftuler Bac, 2017: 424). The increasing focus on the selective pattern has survived until today despite the accelerating retreat from a full membership perspective. To ease these continuing frustrations, this new format of relations experienced another initiative with the EU-Turkey cooperation deal for refugees of March 2016 (Turhan, 2017: 2). The agreement was essential to control the massive effects of Syrian conflict while simultaneously expanding the scope of external differentiated integration between the EU and Turkey (Turhan, 2017: 3). Similarly, the selective alignment on transport was also born out of the need to escape a political crisis.

Regarding the question of the factors leading Turkey to take a selective rather than uniform approach on transport, Muftuler Bac and Luetgert (2016: 10) suggest various factors driving states to initiate flexible integration efforts. They argue that both member and non-member states selectively opt-in or out in particular policy areas because of various dynamics. These include domestic politics, political realities, national sovereignty concerns, and the preferences and veto powers of existing member states (Muftuler Bac and Luetgert, 2016: 10). The critical factor regarding Turkish transport was the veto power of existing member states, which was basically about the negative views of existing member states towards Turkish accession, then forced Turkish transport officials to search for alternative channels. Specifically, the EU's decision to suspend the transport chapter of the membership negotiations because of Turkey's refusal to recognize Cyprus and implement the Protocol as a benchmark (Turkey Directorate for EU Affairs, 2018) eliminated the 
possibility of uniform integration in this policy area. This left no other option for Turkish officials except finding new channels to continue transport alignment.

Schimmelfennig et al. (2015) offer another explanation in terms of external differentiated integration for Turkey's selective participation in transport. Turkey and the EU still dependent on each other's markets and transport routes for reasons listed in the introduction. Therefore, economic rationality supports the alignment process and drives integration. Conversely, strong politicization due to the EU's political decision to suspend the negotiation chapter deadlocked transport integration. When high interdependence and politicization clash, a non-member state selectively chooses to opt-in or out, which is what Turkey did on transport. It decided to opt-in, paving the way for alignment outside of the full membership prospect by creating alternative flexible instruments with the EU. These include the TINA (Trans-European Network for Transport Study) program, Turkey's inclusion in pre-accession IPA funds, the TRACECA and TWINNING programs, Single European Sky agreements, the creation of the Transport Operational Program to regulate IPA funds and increase competitiveness (European Commission, 2018), and EU investments for selected Turkish domestic transport projects.

This study argues that the reasons behind the creation of these new instruments and strong alignment as a result could be investigated under two factors: favorable domestic political preferences and supportive non-state institutions. In terms of the classification developed by Zhelyazkova (2014), Turkey can be considered a selective participant in transport, which does not necessarily mean full implementation of the EU acquis. Although the above instruments have encouraged Turkey's transport sector to reach EU levels, the country remains far from full engagement for the same reasons that led the country to opt-in in the first place.

\section{Turkish Transport and EU Alignment}

\section{EU's Transport Policy}

Involves uniformity or selectivity, the main themes of EU transport policy have the same expectancies from member and non-member states. By opting-in, Turkey also decided to align with these provisions of the EU acquis. The latest version of the EU's transport policy, officially the "Common Transport Policy", was settled by the Treaty on the Functioning of the European Union, signed in 2007 in Lisbon. Articles 90 to 100 define the desired measures to improve transport infrastructure and safety, and remove the remaining bottlenecks hindering a single transport market (European Union, 2012). The policy's roots go back to the Treaty of Rome, through which the first members aimed to achieve the four freedoms of the emerging common market (European 
Commission, 2014). Reforms continued with the Treaty of Maastricht, which established trans-European networks, expanded connections and modernized transport infrastructure (European Commission, 2014). The policy's decisionmaking structure moved to co-decision in Amsterdam (European Commission, 2014). The 2011 White Paper, called the "Roadmap to a Single European Transport Area", provided the recent shape of the policy through both intermodal and multimodal market approaches (European Commission, 2014). These reforms aimed to promote an integrated transport policy to enable member states to contribute to growth, employment and sustainability (European Union, 2017).

For every single transport mode, the EU acquis prioritizes and strategizes similar themes of efficiency, sustainability and accessibility. In aviation, for instance, the EU promotes a "Single European Skies" initiative to meet future demand and ensure safe links between air services and the environment (Eurocontrol, 2017). The EU's external aviation policy is defined by its "Open Skies" agreements to regulate air services and extend bilateral agreements (European Union, 2017). The EU's aviation acquis requires more accessibility, less pollution, new technologies and safer skies (European Union, 2017). Similarly, EU maritime policy promotes an expanding liberal maritime market, protection of the marine environment and safety. For ensuring a single maritime policy, the EU demands that member states align with the legislation and modernize their infrastructure (European Commission, 2014). Liberalization of transport markets is indispensable for the well functioning of the single market and free movement of goods. The EU's neo-liberal market structure also makes it inevitable. The EU's approach also encourages participants to liberalize their rail markets (European Union, 2017). Another important piece of rail legislation concerns modal shifts from road to rail in both freight and passenger transport. For both liberalization and modal shifts, the EU encourages the creation of technologically advanced high-speed rail networks, as explained in four different railway packages (European Union, 2017). Regarding road transport, the EU stipulates common standards for road charges, driving times and car emissions. The European Commission also focuses on traffic and environment protection. Common standards include road safety and modernization, maximum driving times through tachometer usage and no discrimination on road charges (European Commission, 2014). The EU has proposed a $60 \%$ cut in exhaust emissions and wants to abolish any remaining closed markets by the end of 2050 (European Union, 2017). Another EU initiative in transport policy is Trans-European Networks (TEN-T) to create the infrastructure for a transport corridor to physically connect all member states (European Commission, 2017b). TEN-T also aims to overcome the problem of unequally distributed transport infrastructure across both member and non-member participants (European Commission, 2014). 
It is also important to remember that the EU's transport norms and TEN-T goals are separate negotiation chapters for Turkey's full membership application. However, this uniform approach to integration has been discarded for reasons mentioned earlier. Nevertheless, Turkey decided to opt-in to the policy area without being a full participant and using alternative instruments.

\section{Turkey's Alternative Instruments for transport integration}

As stated in the main argument, Turkey's rational decision to participate selectively in the policy area has forced both state and European officials develop alternative, flexible instruments for Turkish alignment. One of the most prominent is Turkey's inclusion in the TINA (Transport Infrastructure Needs Assessment) program. This offers Turkey financial assistance arranged through the IPA (Instrument for Pre-Accession Assistance), which is also financed through the European Commission (Turkey Directorate for EU Affairs, 2018). Using TINA resources, Turkey and the EU have designed the Transport Operational Program for relevant alignment projects. These projects include high-speed railway construction and modernization (Ankara-Istanbul, IrmakKarabuk-Zonguldak, Samsun-Kalın), and planning for the Halkali-Kapikule line (Turkey Directorate for EU Affairs, 2018). Financial assistance has also continued with IPA II funds for modernizing Turkey's current railway infrastructure, encourage intermodal transport and improve accessibility to all modes (Turkey Ministry of Transport and Infrastructure, 2017a).

Turkey has also joined the TRACECA (Transport Corridor: EuropeCaucasus-Asia) project. This aims to establish a transport corridor between Asian markets and the common transport market to provide balance between modes, environmental protection, social welfare and modern infrastructure offering accessibility and wider choice across transport modes (Kuscu, 2011). Regarding the transport modes specifically, Turkey regulates its road alignment through a positive agenda settled between KGM (Turkey General Directorate for Highways) and the EU. They are currently working on joint projects in framework programs to ensure travel safety on roads (Gebze-Izmir and North Marmara motorways) and Turkey's inclusion in environmentally friendly EU road projects such as ECOLABEL (KGM, 2017a). In aviation, the Turkish Directorate General of Civil Aviation (DGCA) has joined EU TWINNING projects to strengthen the administrative capacity of air transport institutions and support the disposition of EU legislation in Turkey (DGCA, 2017). Turkey has also become an official part of EASA (European Aviation Safety Agency) and obliged to apply common European rules on air travel safety (DGCA, 2017).

The final alternative alignment instrument is the EU's direct investment in Turkish domestic transport projects beyond the alignment programs. One 
important example of this investment strategy is the construction of Marmaray, a rail link between Asia and Europe under the Bosphorus. The project is partly financed by the European Investment Bank (EIB) (Togan, 2016). Because this bank only funds EU projects concerning alignment, Marmaray is counted as a partly EU initiative. The EU is involved due to the project's ability to provide balance between transport modes (EU Delegation in Turkey, 2014).

Even though the negotiation chapter is currently suspended, these new instruments have enabled Turkey to move forward in transportation. In addition, the positive agenda established between the sides has enabled the achievement of several alignment results, mostly being closely linked to the creation of flexible instruments. The resulting achievements in alignment are clearly visible in every transport mode. The positive atmosphere has automatically affected Turkey's state-level projects. The National Strategic Plan of 2014-18, prepared by the Ministry of Transport, accepted EU alignment as a state goal and considered integration a decisive factor for domestic transport decisions (Turkey Ministry of Transport and Infrastructure, 2017b). Within the plan, the ministry prioritized railroads, proposed new high-speed rail lines, and aimed to ensure maritime safety and more accessibility to air travel (Turkey Ministry of Transport and Infrastructure, 2017b). Linked to the EU's modal shift approach, full liberalization of the rail market was a major part of the new Turkish transport vision (Turkey Ministry of Transport and Infrastructure, 2017b). To achieve these domestic aims, the ministry authorized the Transport Operational Program along with the EU, which includes infrastructure, compatibility and combined transport projects (Turkey Ministry of Transport and Infrastructure, 2017c). The program also included technical assistance projects for strengthening the administrative capacity of the emerging Turkish air industry (Turkey Ministry of Transport and Infrastructure, 2017c). Moreover, Turkish state also included alignment in other domestic transport initiatives, such as the National ITS strategies, the National Plan on Climate Change and the Tenth National Development Plan.

Under TINA, which primarily aims to establish a multimodal transport network in Turkey, 15 separate road-building projects were launched to provide a 15,200-km road network in the EU's TEN-T road section (Isik, 2012). Meanwhile, infrastructure developments like highway construction have made substantial progress, with 2, $542 \mathrm{~km}$ completed in the last sixteen years (KGM, 2017b). Legislative alignment with the EU has also been strengthened by the settled positive agenda, whereby Turkey made digital tachometers obligatory in 2011, became a part of the ADR Convention (International Carriage of Dangerous Goods) and the Convention on Road Traffic, and harmonized driving licenses with EU standards (Turkey Directorate for EU Affairs, 2018). The EU has also invested in 23 road inspection stations (Turkey Ministry of 
Transport and Infrastructure, 2017c). Due to this progress, the European Commission (2016) in its 2016 Progress Report evaluated Turkey's road transport sector as the most closely aligned with EU imperatives. This can be considered a huge policy success, given that the EU and Turkey could only use alternative strategies. Turkey continues to respect the EU acquis on technical inspections and EU safety policies (European Commission, 2016), and is very close to agreement on the long-standing road transport quotas problem.

Aviation is another success story. The Turkish government adopted the accessibility clause of the EU acquis as a domestic motto, "Air transport is the people's transport", to ensure that the state took the modernization attempts of the national aviation market seriously. The aim matched the EU's goal of enabling Turkish citizens to enjoy the convenience of modern aviation. Through alternative instruments, a rapid alignment started. The first sign was the 2003 market liberalization, which created economic growth in the sector (Gerede, 2015). Liberalization resulted in steady growth of $10 \%$ per year and contributed to modern and secure domestic air transport (Turkey General Directorate of State Airports Authority, 2014). Steady growth was also seen in airport infrastructure as well, with a doubling in the number of airports from 26 to 53 between 2003 and 2014 (Servantie, 2015). As Turkey adopted market liberalization, other alignment models continued. For example, the EU-Turkey Horizontal Aviation Agreement was opened for negotiations in 2010 as part of the "Open Skies" deal (Turkey Directorate for EU Affairs, 2018). Turkey also became a part of EU-funded projects for institutional and administrative capacity-building programs, supervision of civil aviation navigation services and trading schemes for emissions (Turkey Directorate for EU Affairs, 2018). Although Turkey is not a member state, the EU allowed it to join the EUROCONTROL and EASA rules (Turkey Ministry of Transport and Infrastructure, 2017d). Finally, TWINNING projects in aviation helped Turkey to complete its project goals of building emission-evaluating facilities and administrative capacity (Turkey Ministry of Transport and Infrastructure, 2017d).

Remarkable progress was also achieved in maritime affairs, where alignment efforts strengthened regardless of the current state of relations, especially for areas where EU alignment requires international convention rules as a precondition for compatibility. One of the results of this positive approach was re-categorizing Turkish flag carriers as low risk (white list) not high risk (black list) under the Paris Memorandum on Port Control, which is an integral part of EU integration (Turkey Directorate for EU Affairs, 2018). International Maritime Conventions, such as the "Protocol on Preparedness, Response and Cooperation on Pollution" and the "Convention on Facilitation of International Maritime Traffic", were harmonized with domestic maritime legislation as part 
of EU alignment (Turkey Directorate for EU Affairs, 2018). Finally, Turkey upgraded its legislative compatibility in maritime surveillance by adopting International Maritime Organization (IMO) rules and joining the International Mobile Satellite Organization (Turkey Directorate for EU Affairs, 2018).

After many decades, the positive agenda between the EU and Turkey and the neo-liberal transport policies of the current Turkish government have made Turkey's railways an indispensable part of state policies. Subidey Togan (2016) acknowledges the role of the EU and its instruments in improving this sector. The signature EU project has been rail market liberalization. Despite setbacks in general relations, Turkey passed a market liberalization law in 2013 with a 5year transition period for necessary adjustments (Togan, 2016). The details have been filled in by necessary by-laws concerning access to railway infrastructure, capacity allocation, transport of dangerous goods, investigation of accidents and safety (Turkey Directorate for EU Affairs, 2018). Through TINA participation and IPA funds, the Ankara-Istanbul high-speed rail line is operational, the Irmak-Zonguldak line has recently opened and the SamsunKalin line is nearing completion (Turkey Directorate for EU Affairs, 2018). This modernization has increased the length of high-speed railways in Turkey from $888 \mathrm{~km}$ in 2012 to $1,213 \mathrm{~km}$ in 2016 (TCDD, 2017). Between 2004 and $2016,1,805 \mathrm{~km}$ of new railway lines were completed (TCDD, 2017). Finally, through direct investment funds financed through the EIB, the Marmaray project is now fully operational.

\section{Reasons behind Turkey's accession in transport}

The preceding sections have briefly analyzed the results of Turkey's decision to opt-in during such problematic period when both Turkey's membership prospects and completion of the transport chapter remain far away from exhibiting a uniform integration approach. After the EU suspended the transport chapter, there was simply no other way besides differentiation. Nevertheless, both sides have continued a positive agenda through alternative flexible instruments to promote alignment. The previous section discussed the current benefits of Turkey's gradual implementation of its selective participation in the EU transport acquis. However, the reasons behind this participation need careful analysis to determine how Turkey is gradually aligned or not. Here, we propose two different factors for Turkey's decision to selectively participate as a EU agent on transport. The first is the collaborative domestic political agenda while the second is the substantial support from nonstate actors in Turkey. Both of these two motivations could be understood through the theoretical lenses of rationalist institutionalism.

Rationalist institutionalism defines the actor motivations towards the EU alignment process as highly pragmatic and based on constant cost-benefit 
calculations. These calculations might include the membership benefits and adoption costs for the applicants of the EU (Schimmelfennig and Sedelmeier, 2002). Therefore, these particular favorable conditions and anticipated costs may determine the behavior of the member or applicant states (Schimmelfennig and Sedelmeier, 2002). The states' decision-making are prone to change on the basis of instrumental domestic concerns where bargaining, negotiation and coalition formation is necessary for any calculation of the domestic players (Oguzlu, 2010-11). The theory also claims that states are unitary actors and very eager to use international institutions like the EU as a utility-maximizing bodies to improve the effectiveness of common policies (Wagner, 2003). In this case, with regard to the main argument of this research, we could claim that rational calculations of both state decision-makers and supporting institutions paved the way for creating above alternative channels in a very tough period of bilateral relations.

\section{Domestic Political Agenda}

Actor specific interests and their interest-based decision-making is one of the cornerstones of the rationalist institutionalism (Rittberger and Schimmelfennig, 2006). Since the EU accession process changes the opportunity structures for actors involved, domestic change is inevitable (Borzel and Soyaltin, 2012). As a result, an actor expects to create favorable domestic conditions and new benefits when interacts with the EU. Therefore, the first reason for Turkey's selective alignment on transport could be the continued conformity of the AKP's domestic transport agenda with the EU norms on transport. The EU acquis also promotes guidelines and push factors for domestic projects, which the AKP could derive electoral gains in the domestic political sphere. This enabled the AKP government and the EU to reach a rather silent consensus to maintain the win-win or utility-maximizing structure of alignment even though membership relations were deteriorating. In addition, the incumbent AKP government had nearly reached two decades of administration, so the party's agenda, goals, manifesto and even slogans were inevitably intertwined with state policies. Today, official state documents, such as the Ministry of Transport and Infrastructure Action Plan (Turkey Ministry of Transport and Infrastructure, 2017b), considered 2003 (a year after AKP's first election victory) as the turning point for Turkish transport while openly criticizing previous governments for their incapacity. Thus, the AKP's agenda was an important element for enabling EU harmonization to continue through alternative means.

The rationality behind the AKP's support for the EU transport acquis is based on the desirability of common aims for domestic purposes, such as election promises. AKP has constantly used slogans that emphasize EU accessibility and modernization projects, such as "Railways will be liberalized", 
"Marmaray has been constructed" and "Air transport is the people's transport" (AK Parti, 2018). Although these slogans were used in local elections to win votes, this does not reduce the instrumental value of the EU transport acquis for domestic benefits. Overall, AKP's manifesto, new domestic projects, local transport strategies and official party comments on transport policy indicate strong commitment to EU integration. One of the most visible examples is the party strategy document, which claims that AKP transport strategies are already aligned with European aims (AK Parti, 2018). This latest strategy statement refers to the party's goals of preparing a master plan on transport, railway modernization, road safety and full liberalization of ports and the railway market (AK Parti, 2018).

The AKP party manifesto is another indicator of Turkey's decision to continue selective alignment. The manifesto openly supports and refers the importance of a European-style balanced transport mode structure and an environmentalist agenda regarding the construction and modernization of various projects (AK Parti, 2018). AKP's political vision on transport generally agrees with persisting with integration so long as it matches the universal approach that Turkish citizens deserve (AK Parti, 2012). This encourages the creation of alternative instruments rather than uniform integration. Domestic political support is an important element of a rationalist bargain, so it is vital that the AKP government still agrees with the European Commission. The AKP government has also constantly used the EU process and acknowledged its instrumental value while declaring their domestic achievements to the public. So far, the AKP has promoted the use of tachometers in road transport, rail market liberalization, high-speed railway line construction and modernization of all transport infrastructures as internal party projects and accomplishments (AK Parti, 2018). Although the AKP did not mention the creation of alternative instruments and the role of the EU to the electorate, this does not challenge the instrumental value of alternative alignment instruments for the party.

For the future, the AKP government also envisages continuing with alignment. Besides its strong willingness, the party has also ensured compatible technological progress with intelligent transport systems, increased security and safety to prevent accidents in every transport mode, full liberalization of transport markets, including the remaining parts of the railway market, and new modernization projects (AK Parti, 2018). Thus, Turkey's selective participation in EU transportation development, implemented by successive AKP governments, is closely related to a supportive domestic political agenda. The involvement of domestic politics may be both desirable and undesirable for integration but in this case, the survival of a positive Turkey-EU relationship heavily depended on domestic politics. However, since domestic preferences change rapidly due to unstable national interests and priorities, consistency may 
be hard to achieve. Although AKP is still willing to cooperate with the EU over selective participation in the transport agenda, selective participation may result in selective implementation.

\section{Supporting non-state actors}

The second factor behind Turkey's decision to cooperate with the EU against turbulent years is the size and effectiveness of non-state actors that contribute to and support the process in transport. As a mediating factor, rationalist institutionalism identifies both the preferences of the government and the existence of veto players to determine the future of the relations with the EU (Ozer and Nas, 2012). An increased number of veto players could diminish the effectiveness of the final reward. Therefore, for the sake of alignment process, the EU needs domestic allies (Ozer and Nas, 2012) or supporting institutions to empower domestic reform (Borzel and Soyaltin, 2012).

Since the membership as an ultimate reward is currently lost in the EUTurkey relations and the loss of conditionality is evident, motivating the state could be very problematic. For continuing to the process via alternative channels, the support and gains of non-state groups are vital. Plenty of groups are working nationwide and advising state officials and civil society to maintain progress on alignment during these turbulent times. These non-state actors are mainly national business organizations and civil society groups that raise awareness about specific transport mode issues. Notable groups include UND (International Freight Forwarders Association), UTIKAD (International Freight Forwarders and Logistics Service Providers Association), DTD (Railway Transport Association), the Highway Traffic and Road Safety Association, TURKLIM (Port Operators Association of Turkey), IMEAK Turkish Chamber of Shipping and AUSDER (Association of Intelligent Transport Systems).

UND is a remarkable example. This business group has worked as a locomotive of integration for years and has been very influential in finding alternative channels to contribute to alignment by solving bottlenecks. UND has played an important role during Turkey's struggle to solve the long-standing road transport quotas problem, which arises from ambiguity in EU law and its differing interpretation in member state legislation. After the Treaty of Lisbon, EU member states started to use their status to negotiate transport agreements with non-members, such as Turkey (Servantie, 2017:7), which signed 25 bilateral agreements with EU member states to strengthen alignment with the common transport policy (Servantie, 2017:7). However, despite these bilateral agreements and the clear rules under the Customs Union relating to the free movement of goods and services, some member states imposed significantly limited quotas and other administrative difficulties while granting transit permits to Turkish trucks (Servantie, 2017:7). After many years of silence, a 
UND member Turkish logistics firm, which had been subject to the quotas, brought the issue to the ECJ (Servantie, 2017:8). Through UND mediation and using the ECJ as an alternative ground for debate, this important integration bottleneck was now openly discussed both nationally and supranationally (Servantie, 2017: 8). Given that both the EU and Turkey were losing trade worth 3.5 million Euros (Servantie, 2017:8), UND's actions were critically important. UND has also attended coordination meetings with DG Move and DG Near in the European Commission, as well as the European Parliament Trade Committee (UND, 2015).

As one can see from this example, the supportive power of non-state actors can help integration proceed through alternative channels. Other business and civil society groups have contributed to solving bottlenecks. TURKLIM (2017), which is a maritime sector group with coordinative relations with the European Commission, recently contributed by participating in instruments such as an ongoing EU project to establish offices for promoting professional qualifications and information for maritime freight forwarders. Another maritime group, IMEAK Turkish Chamber of Shipping (2016), joined parliamentary negotiations with the Brussels-based EUROCHAMBRES (Association of European Chambers of Commerce and Industry) to protect Turkish transport interests and assist group members regarding EU integration. These efforts helped the national maritime industry play a significant role in the reclassification of Turkish-flagged shipping, mentioned above (IMEAK Turkish Chamber of Shipping, 2016). Civil society groups have also been interested in road transport issues, and road safety and security. For example, along with other state and non-state actors, a civil society initiative called the Highway Traffic and Road Safety Association (2017) aims to cooperate with EU institutions to support the acquis in eliminating Turkey's significant road safety problems. These multi-level initiatives and support from lower levels of jurisdiction have ensured the continued alignment of Turkey's transport sector with the EU.

\section{From selective participation to selective implementation}

Regardless of the benefits of alternative instruments for alignment, selective participation does not necessarily lead to a full implementation, as is the case with Turkey's transportation sector. In line with Zhelyazkova's (2014) hypothesis regarding the domestic effects of differentiated integration, the Turkish case indicates that a certain level of alignment is possible through selective participation, although this does not automatically upgrade the country to the level of fully aligned member states. Thus, there are areas for Turkish transport to improve as it remains far from achieving complete harmonization. Instead, there is selective implementation from selective participation. This means that it is critical to show that alternative instruments are useful and 
motivational to continue the process but also limited compared to a full accession process with the reward of membership. If the EU fails to provide the necessary political instrumentality for domestic policy makers, Turkey will tend to stall implementation in some areas. Similarly, when a supportive non-state actor sees a specific policy as a threat to their business interests, they will be equally unenthusiastic about alignment.

From this perspective, it can be assumed that integration actors in this process are highly selective based on their rational gains. In Turkey, transport policy is never regarded as a merely technical issue and a simple part of the free movement of goods. Instead, it is a useful instrument in the domestic political arena. Accordingly, EU integration of transport also falls within this sphere. This instrumentality leads to greater micro-level management and selectivity, as for example regarding the establishment of different high-speed railway lines. Even though the construction of the Halkali-Kapikule line is a EU-supported project, the prioritization went to a different route depending on domestic policy calculations. Thus, while the European connection (Halkali-Kapikule section) of the Ankara-Istanbul railway remains in the planning phase, the other line, Baku-Tbilisi-Kars, has been rapidly completed. Altun (2017) defines the latter as a historic turn in transport politics in that Turkey is finally turning away from the West. He describes the project as a strong response to Western hypocrisy towards Turkey. This clearly showed that the domestic policy calculations are not fixed and still heavily depended on national concerns.

Marmaray provides another example of micro-management of implementation. The line twice received EIB financing because it was intended to connect Asia and Europe for both passenger and freight transport (EU Delegation in Turkey, 2014). The passenger route was established very quickly and, as stated earlier, depicted as a domestic victory for the AKP government and highlighted in their election manifestos. Meanwhile, as the less instrumentally beneficial part, the freight route remains unfinished. Such microselective implementation methods based on political desirability have appeared in other railway projects. Although railways are the government's prize projects, modernization of existing lines remains in doubt. The latest accident on the Tekirdag sector of the Kapikule railway once again brought Turkey's railway modernization into question. There were serious allegations against the government concerning their lack of coordination of EU funds reserved for modernization (Birgun, 2018). In addition, domestic politicians also joined the debate concerning political selectivity. For example, the President of the Istanbul Metropolitan Municipality, Mevlut Uysal, warned voters that transport projects would be prioritized according to AKP votes in each area (Hurriyet, 2018). 
According to Erel (2002), this problem of micro-management results from irregular policy making with unplanned implementation. Erel (2002) found that unplanned and selective implementation, combined with Turkey's ongoing capacity problems, has unfortunately enabled domestic decision makers to make their choices according to political interests and pressures. Another example of this unplanned implementation concerned the highly regarded rail market liberalization. Turkey selectively decided to liberalize its market while ignoring the importance of other integration areas after liberalization, such as employment rights and safety. Even though officials warned about the possible risks of liberalization for working conditions and railway safety (Milliyet, 2013), no action has yet been taken to alleviate these concerns. Meanwhile, Turkey's railway sector has reported financial losses close to 60 million Euros despite liberalization (Fortune, 2015).

There have been similar outcomes in other transport areas where domestic political instrumentality is low. Although intelligent transport systems (ITS) have gained attention recently, Turkey has had no significant achievements in alignment concerning the ITS acquis (AUSDER, 2016). Regarding road safety, fatalities are still increasing while alternative instruments are lacking. According to a KGM (2016) report, there were 1,182,496 accidents in 2016 compared to 950,120 in 2008. The Highway Traffic and Road Safety Association (2017) has criticized the state over these rates and emphasized that financial assistance and alternative support for road safety are inadequate because of the political measures behind state support (Fortune, 2014). According to the Highway Traffic and Road Safety Association (2017), there is a double standard because potential safety measures are undermined by politically motivated policy making (Fortune, 2014). This civil society group also claims that the state is reluctant to act because the current solutions are politically undesirable (Fortune, 2014).

Finally, non-state actors are themselves not immune to selective implementation since their support falls if EU acquis conflicts with their sectorial interest. A good example is the struggle between the rail and road sectors regarding EU integration. Turkey's transport sector is very heavily dependent on road transport (Togan, 2016: 38), which currently accounts for $89.9 \%$ of domestic freight haulage (TCDD, 2017). However, the EU has urged member and non-member states to balance between modes by shifting the burden from road to the rail for greater efficiency and sustainability. The road transport and freight lobbies in Turkey have both been highly effective in blocking this shift due to their concerns over loss of market share. So far, there has been no visible shift in the balance between the modes. The state has also remained silent over the issue because road building is a far cheaper option than railways. However, road groups still insist that Turkey should develop a 
transport regime outside of the EU to escape from this shift in the balance and possible market losses (Dunya, 2013). The road lobbies also evaluates the balancing scheme as a trap for Turkey's freight sector (Dunya, 2013).

\section{Concluding Remarks}

There are other options beyond the current stalemate in EU-Turkey relations available for the two sides to exploit. Indeed, differentiated integration has always been part of bilateral relations. Starting with the Customs Union, Turkey's integration with the EU and the instruments used have diverged from those of other candidates and moved away from a uniform process. Consequently, a selective, flexible opt-in process has emerged for Turkey that has enabled integration to continue through an alternative model. This brief study analyzed a case directly related to these developments. Turkey's transport policy has strengthened its bonds with the EU during a very unusual period. While relations in general have weakened consistently, transport alignment has progressed.

As the main argument states, the locomotive for this success has been alternative integration instruments and Turkey's selective opt-in to a specific EU policy area. This research argued that several factors might explain this selective participation. Specifically, although the transport chapter is currently suspended, supportive domestic policy structures and support from non-state organizations have encouraged Turkey's alignment efforts even though the membership prospect is lost. However, this study has also showed that selective participation does not necessarily lead to full alignment: Turkey still has a long way to go, which requires eliminating politically motivated micro-level selectivity in implementation of transportation alignment.

This paper also defined the concept of differentiated integration and differentiated integration in Turkey-EU relations. It then examined Turkey's transport sector as a case to identify the reasons behind Turkey's selective participation and implementation of the relevant EU acquis. The paper showed that, although relations are generally tense, the transport sector has moved in a good direction through alignment. While Turkey is certainly still far away from full alignment in transport, the case demonstrates that the EU and Turkey may be able to move towards harmonization through selective, flexible alternative instruments, and by involving Turkey in current EU projects outside of the "one-size-fits-all" approach. This model could indeed be applied to other areas, such as energy and the environment, to show that alignment without membership is both possible and realistic. At a time when no future projection is easy and political decisions are highly unstable, we can conclude that Turkey's transport sector and probably many others may offer new hope for improving relations. 


\section{References:}

AK Parti (2012) “AK Parti 2023 Siyaset Vizyonu: Siyaset, Toplum, Dünya”, 30 Eylül 2012.

AK Parti (2018) “Genel Icraat Kitabi”, <http://www.ililakicraatlar.com> (13 March 2018).

Altun, F. (2017) "Bir aci tren dudugunun dusundurdukleri”, Sabah Gazetesi, 01 November 2017, Istanbul.

Andersen, S. and Sitter, N. (2006) "Differentiated integration: What is it and how much can the EU accommodate?", Journal of European Integration, 28(4): 313-330.

AUSDER (2016) "Akilli Ulasim Sistemleri: Ulke Mevzuatinin Genel Cercevesi”, AUSDER Report No. 2, AUSDER, İstanbul.

BBC (2018) "Macron: Cumhurbaskani Erdogan'in Turkiyesi Kemal'in Turkiyesi degil", 27 August 2018, <https://www.bbc.com/turkce/haberlerdunya-45320424> (5 September 2018).

Borzel, T. and Soyaltin, D. (2012) "Europeanization in Turkey: stretching a concept to its limits?", KFG Working Paper Series, 36: 1-22.

DGCA

"International

Relations", $<$ http://web.shgm.gov.tr/tr/uluslararasi-iliskiler/2188-uluslararasi-iliskiler> (24 February 2017).

Dunya (2013) "Turkiye, AB 'den bagimsiz bir ulastirma politikasi belirlemeli”, Dunya Gazetesi, 04 February 2013, Istanbul.

DW (2017) “Türkiye'nin AB Süreci: Hayal kirikligi ve bikkinlik”, 18 October 2017, <https://www.dw.com/tr/türkiyenin-ab-süreci-hayal-kirikligi-vebikkınlık/a-40968837> (18 April 2018).

Erel, A. (2002) “Türkiye'de Ulaştırma Sektöründe Sorunlar ve Eğitim”, paper presented at the VI. International Conference in Economics, Ankara, 11-14 September.

EU Delegation in Turkey (2014) "EUR 200 Million Further EIB for the Marmaray Project in Turkey", 05 August 2014, $<$ https://www.avrupa.info.tr/en/pr/eur-200-million-further-eib-marmarayproject-turkey-1185> (6 November 2016).

Eurocontrol (2017) "Pan-European Single Sky: Single European Sky", $<$ https://www.eurocontrol.int/dossiers/single-european-sky> (15 June 2017).

European Commission (2014) "Transport: Connecting Europe's citizens and businesses", (The European Union Explained), 3 November 2014.

European Commission (2016) "Commission staff working document: Turkey 2016 Report”, SWD (2016) 366 final, 9 November 2016. 
European Commission (2017a) 'President Jean-Claude Juncker's State of the Union Address 2017", 13 September 2017, <http://europa.eu/rapid/pressrelease_SPEECH-17-3165_en.htm> (18 July 2018).

European Commission (2017b) "Mobility and Transport: Trans-European Transport Network", <http://ec.europa.eu/transport/infrastructure/tentec/ tentecportal/site/en/connectingeurope.html $>$ (12 May 2017).

European Commission (2018) "IPA Transport Operational Programme in Turkey", <http://ec.europa.eu/regional_policy/en/funding/ipa/turkey/ transport/> (27 August 2018).

European Parliament (2016) "Differentiated integration in the European Union" $<$ http://www.europarl.europa.eu/RegData/etudes/ATAG/2016/573961/EPRS _ATA(2016)573961_EN.pdf> (14 January 2017).

European Union (2012) "Consolidated version of the Treaty on the functioning of the European Union", C 326/47 (Official Journal of the European Union), 26 October 2012.

European Union (2017) "EU by topic: EU transport policy", $<$ https://europa.eu/european-union/topics/transport_en> (23 June 2017).

Fortune (2014) “Turkiye'de 7 kisiden biri trafik magduru”, 16 November 2014, $<$ http://fortuneturkey.com/turkiyede-7-kisiden-biri-trafik-magduru3086\#popup > (16 February 2016).

Fortune (2015) "60 milyon euroluk hizli tren zarari", 23 June 2015, $<\mathrm{http}$ ://www.fortuneturkey.com/60-milyon-euroluk-hizli-tren-zarari-14952> (16 February 2016).

Fumasoli, T., Gornitzka, A. and Leruth, B. (2015) "A Multi-Level Approach to Differentiated Integration: Distributive Policy, National Heterogeneity and Actors in the European Research Area", ARENA Working Paper, 2: 1-29.

Gerede, E. (2015) "Havayolu Tasimaciligi ve Ekonomik Duzenlemeler Teori ve Turkiye Uygulamasi”, HUD/T-01, (Sivil Havacilik Genel Mudurlugu Yayinlari), February 2015.

Highway Traffic and Road Safety Association (2017) "Tuzugumuz", $<\mathrm{http}$ ://www.trafik.org.tr/kurumsal/tuzugumuz> (18 March 2017).

Holzinger, K. and Schimmelfennig, F. (2012) "Differentiated integration in the European Union: Many concepts, sparse theory, few data", Journal of European Public Policy, 19(2): 292-305.

Icener, E. (2007) "Privileged partnership: An alternative final destination for Turkey's integration with the European Union?", Perspectives on European Politics and Society, 8(4): 415-438.

IMEAK Chamber of Shipping (2016) "2015 Y1lı Faaliyet Raporu ve 2016 Y11 İs Programi”, March 2016. 
Isik, I. (2012) "Integration of Turkey into the Trans-European Transport Network: A Gateway Between the Continents", (Ministry of Transport, Maritime and Communications of Turkey-Presentations), 28 February 2012.

KGM (2016) “Trafik Kazalarinin Ozeti”, (Trafik Guvenligi Dairesi Baskanligi Raporlari), July 2017.

KGM (2017a) "Avrupa Birligi (AB) Calismalari”, $<$ http://www.kgm.gov.tr/Sayfalar/KGM/SiteTr/KgmAbCalismalari/kgm_ab _calismalari.aspx> (9 November 2017).

KGM (2017b) "Istatistikler", <http://www.kgm.gov.tr/Sayfalar/ KGM/SiteTr/Istatistikler/DevletveIlYolEnvanteri.aspx $>\quad(9$ November 2017).

Kuscu, S. (2011) “The European Union Transportation Policy and its Reflection in Turkey", Akademik Bakis, 5(9): 77-91.

Leruth, B., Ganzle, S. and Trondal, J. (2017) "Differentiated integration and disintegration in the European Union: State-of-the-art and ways for future research" ISL Working Paper, 2017(1):1-23.

Milliyet (2013) “TCDD'de ozellestirme tartismalı basladi”, Milliyet Gazetesi, 2 April 2013, Ankara.

Muftuler-Bac, M. and Luetgert, B. (2016) “The European Union's alternative models for maximizing its integration strategy for candidates and neighbour states: A Process of external differentiation", MAXCAP Working Papers, 35:1-44.

Muftuler-Bac, M. (2017) "Turkey's future with the European Union: an alternative model of differentiated integration", Turkish Studies, 18(3):416438.

Oguzlu, T. (2010-11) “Turkey and Europeanization of Foreign Policy?", Political Science Quarterly, 125(4):657-683.

Onis, Z. (2008) "Turkey-EU Relations: Beyond the current stalemate", Insight Turkey, 10(4): 35-50.

Ozer, Y. and Nas, C. (2012) Turkey and the European Union: Processes of Europeanisation, (London: Ashgate).

Rittberger, B. and Schimmelfennig, F. (2006) "Explaining the constitutionalization of the European Union", Journal of European Public Policy, 13(8):1148-1167.

Schimmelfennig, F. and Sedelmeier, U. (2002) "Theorizing EU enlargement: research focus, hypotheses, and the state of research", Journal of European Public Policy. 9(4):500-528. 
Schimmelfennig, F., Leuffen, D. and Rittberger, B. (2015) "The European Union as a system of differentiated integration: interdependence, politicization and differentiation", Journal of European Public Policy, 22(6):764-782.

Schimmelfennig, F. (2018) "Brexit: differentiated disintegration in the European Union", Journal of European Public Policy, 25(8): 1154-1173.

Servantie, D. (2015) "AB ve Turk Havacilik Politikalarinin Karsilastirmali Analizi”, Iktisadi Kalkinma Vakfi Degerlendirme Notu, No. 154, İktisadi Kalkınma Vakfi, İstanbul.

Servantie, D. (2017) "The quota issue of the Turkish road transport sector in the EU”, IKV Brief, İktisadi Kalkınma Vakfı, İstanbul.

Sputnik News (2018) “Celik'ten AB'ye: İmtiyazli ortaklik teklifi gorursek kapiyi dahi acmayiz", (13 January 2018), $<$ https://tr.sputniknews.com/turkiye/201801131031792455-omer-celikimtiyazli-ortaklik/> (15 June 2018).

TCDD (2017) "Turkish State Railways Annual Statistics: 2012-2016", TCDD Yayin No: 2017-1 (Strategy Development Department Statistics and Analysis Office Reports), 2017.

Togan, S. (2016) The Liberalization of Transport Services in the EU and Turkey, (New York: Oxford University Press).

Turhan, E. (2017) "Thinking out of the accession box: The potential and limitations of internal and external differentiated integration between Turkey and the EU" CIFE Policy Papers, 58: 1-8.

Turkey Directorate for EU Affairs (2018) "Chapter 14- Transport Policy", $<$ https://www.ab.gov.tr/79_en.html> (29 July 2018).

Turkey General Directorate of State Airports Authority (2014) "Havayolu Sektor Raporu” (DHMI Havayolu Sektör Raporlarl), 2014.

Turkey Ministry of Transport and Infrastructure (2017a) "Sectoral Operational Programme for Transport", <http://op.udhb.gov.tr/en/about-us/transportsector-operational-programme-ipa-ii-period-2014-2020> $\quad(1 \quad$ September 2017).

Turkey Ministry of Transport and Infrastructure (2017b) "Ulastirma, Denizcilik ve Haberlesme Bakanligi Stratejik Plani: 2017-2021” (Ulastirma, Denizcilik ve Haberlesme Bakanligi Stratejik Planlari), 2017.

Turkey Ministry of Transport and Infrastructure (2017c) "Ulasan ve Erisen Turkiye 2017: Karayolu” (UDHB Sektorel Projeler Serisi), 2017.

Turkey Ministry of Transport and Infrastructure (2017d) "Ulasan ve Erisen Turkiye 2017: Havacilik ve Uzay Teknolojileri” (UDHB Sektorel Projeler Serisi), 2017. 
TURKLIM (2017) "Hakkimizda", <http://www.turklim.org/hakkimizda/> (14 July 2017).

Turkish Statistical Institute (2018) "Foreign Trade Statistics 2018" $<$ http://www.turkstat.gov.tr/PreHaberBultenleri.do?id=27789> (13 August 2018).

UND (2015) "UND, Kota Sorunlarini AB Parlamentosu Uluslararasi Ticaret Komitesi'ne Anlatt1", 11 December 2015, $<$ http://www.und.org.tr/tr/17948/und-kota-sorunlarini-ab-parlamentosuuluslararasi-ticaret-komitesi-ne-anlatti> (8 July 2016).

Wagner, W. (2003) "Why the EU's common foreign and security policy will remain intergovernmental: a rationalist institutional choice analysis of European crisis management policy", Journal of European Public Policy, 10(4):576-595.

Wallace, H. (1998) "Differentiated integration", in D. Dinan (ed.s), Encyclopedia of the European Union, (Boulder, CO: Lynne Rienner) pp.137-140.

Zhelyazkova, A. (2014) "From selective integration into selective implementation: The link between differentiated integration and conformity with EU laws", European Journal of Political Research, 53(4):727-746. 